\title{
The Evaluation of Curriculum 2013 Implementation in English Subject at Islamic Junior High School Al Madina Semarang
}

\author{
M.H. Setiawan ${ }^{1}$, F.T. Sumaryanto ${ }^{2}$, D.A.L. Bharati ${ }^{3}$ \\ \{mharissetiawan@students.unnes.ac.id ${ }^{1}$, totoksumaryanto@mail.unnes.ac.id ${ }^{2}$, \\ dwi_anggani@mail.unnes.ac.id $\left.{ }^{3}\right\}$ \\ Graduate School, Universitas Negeri Semarang, Indonesia ${ }^{1,2,3}$
}

\begin{abstract}
The study aimed to get information and find out the implementation of curriculum 2013 in English subjects. This study was included in evaluation research with a formative Scriven model. The population in this study is Islamic Junior High School Al Madina Semarang which the school has implemented of curriculum 2013. The sample consisted of 3 classes in the 3 grade levels and 3 English subject teachers with a simple random sampling technique. Data collection in this study used interview, observation, and documentation methods. Data were analyzed by qualitative and quantitative descriptive analysis. The results of the study, the application of the 2013 curriculum in English subjects got scores 3.67, 3.33, 3.40, 3.45 and 3.7 it showed that 5 component aspects have been implemented well, but still need the improvements in several aspects so that the implementation of the curriculum can be even better.
\end{abstract}

Keywords: Evaluation, Implementation, English Subjects, Curriculum 2013

\section{Introduction}

Curriculum 2013 is the latest curriculum that emphasizes the use of a scientific approach, integrative authentic and thematic assessment in learning. This curriculum is expected to be able to create a generation of Indonesians who are critical and creative in accordance with the demands of the times. Education with a scientific approach has the potential to lay an important foundation for children's knowledge and interests in science [1]. At the beginning of implementation, Curriculum 2013 gave rise to many criticisms and protests because it was considered to cause problems. Implementation of Curriculum 2013 still faces one big obstacle that must be addressed, namely the issue of teacher readiness as the key to the success of the implementation [2]. Another problematic implementation is curriculum content and packaging, teacher readiness, and the emergence of multiple interpretations in its implementation [3]. The emergence of various problems in the implementation of Curriculum 2013 did not decrease the enthusiasm of a number of schools that still wanted to implement it, even the schools had the courage to do it independently.

Implementation evaluation of the curriculum 2013 is mostly done in piloting school. The problems faced in primary school teachers in implementing the Curriculum 2013 from the government, institutions, teachers, parents of students and teachers [4]. The teacher's ability to develop, implement, and evaluate Curriculum 2013 was quite good [5]. The preparedness for 
the implementation of the Curriculum 2013 in SD Banaran Kertosono on aspects of school leadership was very good, the creativity of teachers was good, the activities of good students and the academic environment were very good [6]. Similarly, the results of the assistance evaluation conducted by the Research and Development Center of the Ministry of Education and Culture in piloting schools showed that the teachers' understanding of books, lesson plans, learning processes, and assessments was very good.

Evaluation of the curriculum as an attempt to systematically collect information about a curriculum that is used as a material for consideration of the value and meaning of the curriculum in a particular context [7]. The implementation of the curriculum as the operationalization of curriculum concepts that are still potential (written) to be actual in the form of learning activities [8]. Classroom learning becomes a place to implement and test the curriculum. In learning activities, the curriculum concept will be manifested in real terms [9]. Curriculum implementation is the effort needed to ensure the implementation of the curriculum in the school runs well.

The lack of the curriculum 2013 is as follows. (1) Teachers are often mistaken because they assume that with curriculum 2013 the teacher does not need to explain the material to students in the class, even though there is a lot of material that must be explained by the teacher. (2) many teachers who are not mentally ready with curriculum 2013, because curriculum 2013 requires teachers to be more creative in the reality that there are very few such teachers, so it takes a long time to grow the creative thinking of teachers. (3) Lack of teacher understanding of the concept of the scientific approach. (4) Lack of skills teachers design lesson plans. (5) The teacher does not master many authentic judgments. (6) The task of analyzing SKL, KI, KD, Student Books, and Teacher's Books has not been fully worked out by teaching staff, and many teachers have become plagiarists in this matter. (7) No teacher has been directly involved in the curriculum 2013 development process because the government tends to see teachers and students in the same capacity [10].

The curriculum itself is the result of human thought. Then it is only natural if the implementation does not necessarily produce results as expected. In terms of school preparedness in implementing curriculum 2013 includes (1) Student textbooks and teachers manual guide; (2) Curriculum 2013 training for teachers; (3) Learning management; (4) Student services. Learning activities are not only done in the classroom but also everywhere as long as there are learning resources. Carrying out learning there are three stages that go through namely the initial or opening activities, core activities or the formation of competencies and characters, and the final activity or closing [11]. The initial activity is carried out by opening lessons, the teacher fostering an atmosphere that is conducive to learning, and the teacher can also provide initial knowledge tests to students.

The argues that Evaluation of the curriculum is a systematic effort to gather information about a curriculum to be used as a consideration of the value and meaning of the curriculum in a particular context. In this sense there is a context in which the curriculum cannot be applied for a long time or in other words there must be a curriculum development that is in accordance with the times.

From these opinions, an outline can be taken that the learning objectives are competencies that students are expected to have after learning a science or knowledge formulated by educators. Components that are considered in the formulation of learning objectives indicators are those who are expected to achieve the learning goals, expected behavior that can be achieved and conditioning the learning process. A learning process is not only results-oriented (cognitive) but also in the affective and psychomotor domains. 
The description above shows the need for evaluation studies on the application of curriculum 2013 especially on issues related to the implementation of curriculum 2013 in English subjects at SMP Islam Al Madina Semarang. Evaluation activities carried out in research consist of input, component (process), and output components. This study aims to obtain information and to know the feasibility of curriculum 2013 for English subjects in aspects of (1) The use of student textbooks, teacher manuals, and curriculum 2013 training for teachers; (2) Management of learning and student services; (3) The learning process and the assessment process; (4) Student learning outcomes; and (5) Constraints faced.

\section{Methods}

The design used a mix method approach with qualitative research methods supported by quantitative approaches [12]. The Evaluation model of study used the formative proposed by Scriven [13]. The hope is that this research can be used to improve the curriculum that is being developed Data collection on the implementation of curriculum 2013 in English subjects at SMP Islam Al Madina Semarang was carried out by observation, documentation, and interviews.

The sampling technique used was simple random sampling. The sample in this study also represented English subject teachers every level of the class. Samples were taken as many as three classes in three levels of class namely class VII, VIII, IX. As many as 3 of all English language teachers. The data analysis technique used in this research is descriptive qualitative analysis supported by a quantitative approach by describing and interpreting the data from each aspect evaluated, in the form of qualitative data which is concluded in the form of quantitative data. The series in data analysis are data collection, data reduction, data presentation, and conclusion.

\section{Result and Discussion}

The evaluation was by doing consisted of evaluating inputs, processes, and outputs as well as collecting information about the problems faced during the implementation of curriculum 2013.

Table 2. Recapitulation of Input and Process Evaluation Results

\begin{tabular}{|c|c|c|c|}
\hline Num. & Evaluation & Indicators & $\begin{array}{l}\text { Average Score } \\
\text { (Scale 1-4) }\end{array}$ \\
\hline 1 & \multirow{2}{*}{ Input } & Implemented of Learning Management & 3.67 \\
\hline 2 & & Implemented of Student Services & 3.33 \\
\hline 3 & \multirow{3}{*}{ Process } & $\begin{array}{l}\text { Implemented of the Learning Process (Chief and } \\
\text { Teacher) }\end{array}$ & 3.40 \\
\hline 4 & & Implemented of Learning Process (Students) & 3.45 \\
\hline 5 & & Implemented of the Assessment Process & 3.71 \\
\hline
\end{tabular}

\subsection{Evaluation Input}

The benefits of student textbooks cannot be identified because there is no English language textbook for Grade VII students with the curriculum 2013. This is certainly an evaluation for 
the government to prepare the program well before a program is implemented. Students must prepare their own funds to support their learning. As an alternative, students look for material from other learning sources. So it can be concluded that the usefulness of student textbooks cannot be felt because student textbooks are not yet available. The teacher handbook obtained at the beginning of the curriculum 2013 implementation is still very minimal. The teacher still uses books with KTSP that he already has and adds references from other sources. The teacher manual from the government is very much needed because there is no training for teachers from the government.

The Curriculum 2013 training for teachers has been carried out in accordance with the government's target starting from the beginning of the curriculum 2013 implementation. However, in reality, the curriculum 2013 has been implemented with teachers who have not been trained. Teachers only get insight into the curriculum 2013 from the principal's socialization and information from fellow teachers who have received training from the government namely Mathematics teacher, History teacher, and Indonesian teacher.

Learning management activities that consist of adjusting the schedule of the curriculum with the structure of the student interest showed average score of 3.67 which means that aspects of learning management in schools that have implemented curriculum 2013 are well implemented. The evaluation results show that the school has tried well to organize all learning activities to be in accordance with curriculum 2013, although there are still shortcomings in some things such as teacher manuals and student textbooks.

Data on students services are obtained based on interviews conducted with students. Average score of 3.33 which means that the aspects of student learning management services in schools that have implemented the curriculum 2013 are well implemented but there must be an increase in student services in the field of student administration using the internet or online to facilitate students to update data.

\subsection{Evaluation Process}

Aspects of the implementation of the learning process (chief and teachers) and the learning process (students) average score of 3.4 and 3.45 which means that the learning process has been carried out with a pretty good predicate. It can be concluded that the learning process has been carried out in a fairly good category. Teachers who play a big role in the learning process are always required to learn more and be more creative and innovative in facilitating students in learning activities. The hope is that teachers can maintain this condition even more to improve it. If the teacher gets a deeper understanding of the learning process with curriculum 2013, student achievement will increase. Based on the results of the study obtained an average score of 3.71 assuming that the assessment process was carried out in good categories. The evaluation results indicate that each teacher has made an assessment with all types of assessments that are in accordance with curriculum 2013, although there are still difficulties in assessing students objectively and one by one with a very large number of students.

\subsection{Evaluation Output}

Most of the students' have achieved the expected learning completeness. If students have not reached KKM then a remedial is conducted until the student reaches the targeted of KKM. The authority to determine KKM is held by each school with consideration in many ways. The evaluation results show that all students have reached KKM with an average student score of 79.8. It is expected that each school will experience an increase in various efforts made by not 
only paying attention to its value but also producing students who have good attitudes, knowledge, and skills.

\subsection{The problems faced with Implementation the Curriculum 2013}

Aspects of input that were not implemented such as the absence of student textbooks and teacher manuals and the absence of curriculum 2013 training for English subject teachers can have a major impact on the implementation of the learning process and assessment process so that it influences the outputs. The average value of students is 79.8 not maximal because the value can be increased again if the input and process components are implemented well. Most of problems can be faced if the government immediately improves the system and provides firm and appropriate policies. Not only the government but the school must be independent in order to be able to run and implement the curriculum 2013 well. This must also be supported by increasing teacher capacity.

Table 2. The problems faced in Implementation the Curriculum 2013

\begin{tabular}{|c|c|c|}
\hline \multirow{2}{*}{ School name } & \multicolumn{2}{|r|}{ Data Sources } \\
\hline & Chief & Teacher \\
\hline \multirow{2}{*}{$\begin{array}{l}\text { SMP Islam Al } \\
\text { Madina } \\
\text { Semarang }\end{array}$} & $\begin{array}{l}\text { The absence of definite rules } \\
\text { regarding subject teachers is } \\
\text { not listed in the curriculum } \\
2013 \text {. }\end{array}$ & $\begin{array}{l}\text { The teacher is not yet sure about the design of } \\
\text { the learning made whether it is in accordance } \\
\text { with the curriculum } 2013 \text { or not. }\end{array}$ \\
\hline & $\begin{array}{l}\text { The teacher has not mastered } \\
\text { IT (Information and } \\
\text { Technology) well. }\end{array}$ & $\begin{array}{l}\text { The teacher still feels confused about designing } \\
\text { learning that is correct and in accordance with } \\
\text { the curriculum } 2013 \text {. }\end{array}$ \\
\hline
\end{tabular}

Sources: Primary data processed

\section{Conclusion}

Based on the results of research on the feasibility of curriculum 2013 for English subjects at SMP Islam Al Madina Semarang, it can be concluded that from the evaluation component the inputs and processes have been implemented well. The output component shows that all students have reached KKM with an average final grade of students in all three schools amounting to 79.8 , while the KKM is determined which is 75 . The problems faced during the implementation of curriculum 2013 include the absence of regulations and solutions from the government for teachers whose subjects are not listed in curriculum 2013, teachers have not mastered IT well and the lack of training in curriculum 2013 has caused teachers to feel confused in designing the implementation of the right learning.

The implementation of curriculum 2013 in English Language Subjects still needs to get support from the government in the form of student textbooks, teacher manuals, and curriculum 2013 training for English teachers should be increased to schools that implement curriculum 2013 so as not to cause confusion for schools who implement and will implement this curriculum 2013. For school principals to continually disseminate the curriculum 2013 outreach 
to all school members to better understand the curriculum 2013 so that the implementation will be better. For teachers, they must also continue to improve their understanding of curriculum 2013. Students should also maintain their achievements even better. SMP Islam Al Madina Semarang is also expected to continue to provide an understanding of curriculum 2013 for teachers, especially in the delivery of learning materials to attract students' enthusiasm in learning. 


\section{References}

[1] Gerde, H.K.: Using the Scientific Method to Guide Learning: an Integrated Approach to Early Childhood Curriclum. Early Childhood Education Journal. Vol. 41, pp. 315-323. (2013)

[2] Alawiyah, F.: Kesiapan Guru dalam Implementasi Kurikulum 2013. Info Singkat. Vol. 6, pp. 912. (2014)

[3] Ahmad, S.: Problematika Kurikulum 2013 \& Kepemimpinan Instruksional Kepala Sekolah. Jurnal Pencerahan. Vol. 8, pp. 98-108. (2014)

[4] Krissandi, A.D.S and Rusmawan.: Kendala Guru Sekolah Dasar dalam Implementasi Kurikulum 2013. Jurnal Cakrawala Pendidikan. Vol. 34, pp. 457-467. (2015)

[5] Hapsari, D.Y.: Kemampuan Rata-rata Guru dalam Mengembangkan, Mengimplementasikan dan Mengevaluasi Kurikulum 2013. Indonesia Journal of Curriculum and Educational Technology Studies. Vol. 3, pp. 22-28. (2015)

[6] Agustiyana, D and Widodo, S.: Evaluasi Implementasi Kurikulum 2013 Kelas IV SD Negeri Banaran 1 Kertosono. Jurnal Maha Peserta Didik Teknologi Pendidikan Universitas Surabaya. Vol. 2, pp. 3-9. (2014)

[7] Hasan, H.S.: Evaluasi Kurikulum. Bandung: PT Remaja Rosda Karya. (2014)

[8] Majid, A and Rochman. C.: Pendekatan Ilmiah dalam Implementasi Kurikulum 2013. Bandunsg: PT Remaja Rosda Karya. (2014)

[9] Rusman.: Manajemen Kurikulum. Jakarta: PT. Rajagrafindo Persada. (2012)

[10] Kurinasih.: Implementasi Kurikulum 2013, Konsep dan Penerapannya. Surabaya: Kata Pena. (2014)

[11] Mulyasa, H.E.: Pengembangan dan Implementasi Kurikulum 2013. Bandung: Remaja Rosdakarya. (2013)

[12] Kapoyos, R.J., Sumaryanto, F.T., Utomo, U.: Polarization Music Function of Bia in Context of Social Change in Culture in Community Village South District Likupang South Regency of North Minahasa North Sulawesi. Catharsis: Journal of Arts Education. Vol. 6, pp. 123-130. (2017)

[13] Muryadi, A.D.: Model Evaluasi Program dalam Penelitian Evaluasi. Jurnal Ilmiah PENJAS. Vol. 3, pp. 1-16. (2017) 